\title{
Competitive Differences in Input-Factor Utilization among Brazilian Financial Institutions
}

\author{
Gregory G. Lubiani \\ Texas A\&M University-Commerce \\ Srinivas Nippani \\ Texas A\&M University-Commerce
}

Large banks in Brazil offering diverse services enjoy competitive advantages over smaller banks focused on more traditional products. Exactly how resources are utilized to generate these products, though, is still largely unknown. This research illustrates the input-factor utilization practices of institutions in the Brazilian financial services industry through the calculation of own and cross-price, Morishima, and Shadow elasticities. We find distinct and substantial differences in how the banks employ the factors of production, particularly with regard to labor and fixed capital. This novel insight should allow for a more informed and targeted decision-making process for policy makers and industry professionals.

Keywords: Brazil, Factor Substitution, Banking

\section{INTRODUCTION}

Large banks offering a diverse range of services enjoy competitive advantages over smaller banks focused on more traditional offerings. Both economies of scale and scope imply different cost structures and production capabilities between the categories of financial institutions. In a recent study, Barbosa et al (2015) examined the competitive aspects of multi-product banking firms in Brazil. They predict and empirically demonstrate that banks offering classic banking products and other service-oriented banking products have substantially higher market power than banks that offer classic products only. Still needed, though, is an understanding and analysis of how the production technologies were employed to achieve this. Expanding beyond the previous research, we illustrate here the various methods in which three key input factors in the production of banking and financial services are utilized, dependent upon the emphasized banking product of each financial institution. Specifically, this study models the input factor utilization practices for traditional banks in the production of intermediation revenue, and for nontraditional banks in the production of interest and credit revenues separately. Under the constraint of limited resources, this research demonstrates how, with an observed relative price change of the inputs used in the production of these banking services, there is potential for efficiency gains in banks through the reallocation of the input-mix to maintain production levels. This further insight into the production technology capabilities of competing banks with different product offerings in the Brazilian economy may allow for improved policy and managerial decision making. 
The production technologies are illustrated here using the coefficients estimated from the translog cost functions of these conglomerates, modeled separately for traditional and non-traditional banks in Brazil. This methodology has been demonstrated in economic literature to be a very powerful approach to capturing the operational limitations and capabilities of firms in developing economies (de la Rosa, et al., 2017). However, our thorough literature review finds that it has yet to be exploited to its full extent when analyzing the financial services market in emerging markets such as Brazil. Industry professionals and regulatory officials would be better served by an intense illustration of the input-factor relationships that exist for the market. These are presented here through the calculation of own, cross-price, Morshima, and Shadow elasticity estimates, demonstrating the input-factor utilization capabilities of the firms in their production of the various banking services. We further provide evidence of significant structural differences between traditional and non-traditional banks in their use of labor, capital, and fixed capital. Not only does the study find differences in the use of inputs in isolation, but also demonstrates that the inputs may be used as either substitutes or compliments depending on the scope of services offered.

\section{BRAZIL AND THE BRAZILIAN BANKING INDUSTRY}

The Brazilian economy is the eight largest in the world in terms of nominal gross domestic product (GDP), but is in the midst of a recovery from one of the most severe recessions in the country's history. GDP in Brazil averaged $\$ 656.83$ billion USD from 1960 until 2017, reaching a high point of $\$ 2,616.20$ billion USD in 2011. Currently the largest economy in the Latin American region and the second largest in all of the Americas with a GDP of \$2,055.51 billion USD in 2017, the Brazilian economy has the potential to grow substantially more through increased savings and investment (Bacha \& Bonelli, 2015).

Given the important role banks play in the stability and growth of the economy, it is vital that they operate as efficiently as possible to ensure their own sustainability. Historically, Brazilian banks have operated with significantly less efficiency than their counterparts in other Latin American countries, as well as those in the U.S. and Europe (Belaisch, 2003). Barros and Wanke (2014) analyzed the efficiency of Brazilian banks during the period 1998-2010, though, and found that the banks did become more efficient over time. The study further illustrated how increasing economies of scale enjoyed by the large banks, combined with policies of deregulation, decreased costs for firms in the industry.

Further investigating the firm cost structures and resulting industry implications, Barbosa et. al. (2015), using the input prices of funding expenses (natural log of cost of capital), personnel expenses (natural $\log$ of wages) and fixed capital expenses (the natural $\log$ of the ratio of total fixed capital to shareholders equity), found that multi-product firms have significantly higher market power in Brazil. These banks not only enjoy the benefits of economies of scope, but also tend to be the larger financial institutions reaping the rewards of economies of scale as well. We extend the research further, illustrating the efficient production capabilities of Brazilian banks by capturing how the three primary inputs to production for these firms are jointly utilized to produce various bank service offerings. This study examines the employment of these input-factors separately for traditional and non-traditional, multiproduct banks in the market to gain previously unknown insight into the operational differences that may help drive such efficiency disparities.

\section{OPERATIONAL EMPLOYMENT OF FACTORS OF BANKING PRODUCTION}

Within the economic and financial literature, generalized translog modeling has been widely applied in the estimation of production, cost, and profit capabilities of firms. It has been used to examine industries such as healthcare (Lubiani, et. al, 2019), transportation (Ripplinger \& Bitzan, 2018), energy (Ouyang \& Sun, 2015), and economic growth in developing countries (Ramasamy, et al, 2017), among others. Within finance, the approach has recently been employed to illustrate topics such as the economic

content of cost efficiency and bank survival in developing countries (Liang, et al., 2015), competition in banking industries (Rezitis, 2010; Barbosa, et al., 2015), the impact of information technology on bank 
profitability (Gupta, et al, 2018). Its popularity in modeling the economic production technology of firms emanates from its flexibility with no a priori assumptions.

The generalized translog cost function (GTL) is a second-order Taylor series approximation that places no assumptions on the underlying technology, including the scale economies and input factor relationships. It is "generalized" in that it is the most flexible representation of cost/production technology, encompassing within it the possibly more restrictive forms (e.g. Cobb-Douglas). Modeled by Barbosa, et al., (2015) the GTL for Brazilian banks is characterized as:

$\ln T C=\beta_{0}+\sum \alpha_{k} W_{k}+.5\left(\sum \sum \varphi_{i j} \ln W_{i} \ln W_{j}\right)+\delta_{y} \ln Q$

$+.5\left(\sum \sum \varphi_{i j} \ln Q_{i} \ln Q_{j}\right)+5\left(\sum \sum \varphi_{i j} \ln W_{i} \ln Q_{j}\right)+\mu_{i}+\varsigma_{i}+v_{i}$

where $W$ denotes the input factor prices, $Q$ is the income from the possible banking products, $\mu$ and $\varsigma$ represent bank and time fixed effects, with $v$ signifying the error term.

The most commonly employed technique for capturing the input-factor relationships contained within the GTL is the calculation of standard own and cross-price elasticities. These are one-input/one-price estimates that illustrate changes in the quantity of an input used in production for a level of output, given a change in the price of itself or another input. While simplistic in nature, they have the competitive advantage of being the most widely known and understood elasticity measures among industry professionals.

The Allen-Uzawa partial elasticity estimates go further, though, capturing the cross-price elasticity of demand for two input factors from a cost-share weighted perspective. These elasticities are calculated as:

$\delta_{i j}^{A}=\left(\beta_{i j}+C_{i} C_{j}\right) / C_{i} C_{j}$ where $i \neq j$

and:

$\delta_{i i}^{A}=\left(\beta_{i i}+C_{i}^{2}-C_{i}\right) / C_{i}^{2}$ where $i=j$

where $C_{i}$ represents the $i$ th input share of the total costs and $\beta_{i j}$ represents the estimated interaction between the $i$ and $j$ input factors.

The Allen-Uzawa estimates are potentially biased, however, when more than two input factors are present (Stern, 2011). Therefore, it is appropriate in such cases to capture the Morishima elasticity estimates. These are two-factor input ratio changes respective to a change in the price of one of them. As such, there are no own-price results. However, these are not symmetrical, instead capturing how the ratio changes with a possible price change in each separately. These elasticities are calculated as:

$\delta_{i j}^{M}=\partial \ln \left(q_{i} / q_{j}\right) / \partial \ln W_{j}=W_{i} C_{i j} / C_{j}-W_{i} C_{i i} / C_{i}=C_{j}\left(\delta_{i j}^{A}-\delta_{j j}^{A}\right)$

where $q$ is the amount of the input utilized.

Additionally, the Shadow elasticities are a two-input ratio to two-price ratio calculation. They capture how the ratio of inputs used together changes given a shift in the ratio of the prices for both. This allows for the most dynamic system possible, as multiple input factor quantities and prices are both allowed to change simultaneously around constant average costs. As such, there are no own-price estimates and it is symmetrical, calculated as:

$\delta_{i j}^{S}=\left(C_{i} C_{j}\right) /\left(C_{i}+C_{j}\right)\left[2 \delta_{i j}^{A}-\delta_{i i}^{A}-\delta_{j j}^{A}\right]$

Lastly, the own and cross-price elasticities are derived such that: 
$\delta_{i i}^{O}=\delta_{i i}^{A} C_{i}$ where $i=j$

and

$\delta_{i j}^{C P}=\delta_{i j}^{A} C_{j}$ where $i \neq j$

These elasticity results are each noted measures useful in the efficiency evaluation of production technologies (de La Grandville, 1997).

\section{RESULTS}

The three input factors analyzed for each of the financial institutions are labor as captured by the total payroll costs, capital as measured by the total expense of raising funds, and fixed capital as measured by expenditures on owned and leased fixed capital. Every input was then taken as the natural logarithm of the ratio of those outlays to shareholder equity.

\section{TABLE 1 \\ OWN AND CROSS-PRICE ELASTICITIES OF FACTOR DEMAND}

\begin{tabular}{llll}
\hline \hline Factors of Production & $\begin{array}{l}\text { Intermediation } \\
\text { Revenue }\end{array}$ & Interest Revenue & Credit Revenue \\
\hline Labor - Labor & -1.562 & -1.222 & -1.160 \\
Capital - Capital & -0.373 & -0.406 & -0.413 \\
Fx Capital - Fx Capital & -0.515 & -0.554 & -0.529 \\
Labor - Capital & 0.331 & 0.362 & 0.351 \\
Labor - Fx Capital & 0.746 & 0.077 & -0.159 \\
Capital - Fx Capital & 0.314 & 0.361 & 0.397 \\
Capital - Labor & 0.072 & 0.079 & 0.076 \\
Fx Capital - Labor & 0.158 & 0.016 & -0.033 \\
Fx Capital - Capital & 0.305 & 0.350 & 0.385 \\
\hline
\end{tabular}

Note: The own and cross-price elasticity estimates are derived from the cost function estimates provided in Barbosa, et al (2015).

In Table 1 are the own and cross-price elasticity estimates derived from the three original translog cost model equations presented by Barbosa, et al. (2015). The own-price elasticities for each of the three models, in accordance with economic theory, are negative. Further illustrated, the demand for labor in the provision of banking services (both traditional and non-traditional) is elastic. It is important to point out, though, that demand for labor by banks only offering traditional services is significantly more elastic than banks which have expanded their service offerings to include more non-traditional forms. For example, a $10 \%$ increase in the price of labor would lead to a decrease of $11.6 \%$ in the utilization of such by nontraditional banks. However, given that same change in labor wages, those drawing intermediation (traditional) revenue would decrease their utilization by $15.62 \%$.

Additionally, each model reveals inelastic substitutability between the three categories of inputs, with an important exception. Labor and fixed capital appear to be used as compliments by non-traditional 
banks focused on credit revenue. Alternatively, banks focused on more traditional revenue sources use labor and fixed capital as substitutes for one another under the presence of changing market prices. This indicates significant differences in production technology for banks, dependent on the services offered.

TABLE 2

MORISHIMA ELASTICITY ESTIMATES

\begin{tabular}{lccl}
\hline Factors of Production & $\begin{array}{l}\text { Intermediation } \\
\text { Revenue }\end{array}$ & Interest Revenue & Credit Revenue \\
\hline Labor - Capital & 0.704 & 0.769 & 0.765 \\
Labor - Fx Capital & 1.262 & 0.631 & 0.368 \\
Capital - Fx Capital & 0.829 & 0.916 & 0.926 \\
Capital - Labor & 1.634 & 1.301 & 1.237 \\
Fx Capital - Labor & 1.720 & 1.238 & 1.126 \\
Fx Capital - Capital & 0.678 & 0.757 & 0.799 \\
\hline For
\end{tabular}

Note: The Morishima elasticity estimates are derived from the cost function estimates provided in Barbosa, et al (2015).

Previous studies have conclusively demonstrated the potential bias and inappropriateness of the Allen-Uzawa partial elasticities when three or more factors of production are considered (Blackorby \& Russell; 1989). Therefore, we omit the results of the Allen-Uzawa calculations in favor of the Morishima elasticity estimates. These provide more in-depth and useful insight into the input-mix utilization of the banks in our study.

As demonstrated in Table 2, we see instances of considerable variations in the economic structures existing in the Brazilian banking industry. The most considerable changes occur with regard to the inputmix of labor and fixed capital. For instance, with a $10 \%$ increase in the cost of fixed capital, we observe only a $3.68 \%$ increase in the ratio of labor to fixed capital expenditures for banks focused on credit revenue (non-traditional). However, for banks focused on intermediation revenue (traditional), that same cost increase in fixed capital would lead to a rise in the ratio of labor to fixed capital expenses of $12.62 \%$. Conversely, should there be a $10 \%$ increase in cost of labor, we would expect the ratio of fixed capital to labor expenditures to rise by $11.26 \%$ for non-traditional banks and $17.2 \%$ for traditional banks.

TABLE 3

SHADOW ELASTICITY ESTIMATES

\begin{tabular}{lcll}
\hline Factors of Production & $\begin{array}{l}\text { Intermediation } \\
\text { Revenue }\end{array}$ & Interest Revenue & Credit Revenue \\
\hline Labor - Capital & 0.004 & 0.005 & 0.005 \\
Labor - Fx Capital & 0.004 & 0.005 & 0.006 \\
Capital - Fx Capital & 0.067 & 0.060 & 0.059 \\
\hline
\end{tabular}

Note: The Shadow elasticity estimates are derived from the cost function estimates provided in Barbosa, et al (2015).

Table 3 presents the shadow elasticities, commonly the most inelastic of the measures discussed. Similar to the Morishima estimates, these also examine how the ratio of input factor utilization adjusts to price changes. However, rather than a single price change, the shadow elasticity measure is even more dynamic by allowing the utilization to alter in response to a change in the ratio of prices for the two input factors. Here, we observe the greatest amount of response between capital and fixed capital. Among the three models, traditional banks demonstrate the greatest amount of elasticity in the employment of these two factors of production (0.067). 


\section{CONCLUSIONS}

This study demonstrates the methods in which Brazilian banks employ factors of production in the provision of traditional and non-traditional banking services. This is an extension beyond any previous study, providing new insight into the potential drivers of operational and efficiency differences between firms in the market. By analyzing the three input factors using own and cross-price elasticities for factor demand, the findings demonstrate that demand for labor by banks offering only traditional services is significantly more elastic than banks offering non-traditional forms of services. We also find that labor and fixed capital are used as compliments by non-traditional banks, as compared with traditional banks who employ them as substitutes for one-another. This leads to the conclusion that there are significant differences in the production methods practiced by banks in Brazil, dependent on the services offered. This conclusion is further reinforced by the differences found in the derived Morishima and Shadow elasticity estimates.

The new knowledge provided offers a basis as to why traditional banks may choose to remain in the realm of conventional banking services. Having significantly less market power than banks offering diversified services, traditional banks are likely to be more constrained in their potential re-allocation options. With the goal of increasing savings and access to capital to push economic growth, policy makers and industry leaders may use this previously unknown information to better implement decisions affecting input resources and efficiency capabilities in the Brazilian banking industry.

\section{REFERENCES}

Bacha, E.L., \& Bonelli, R. (2015). Accounting for Brazil's Growth Experience-1940-2002.

Barbosa, K., de Paula Rocha, B., \& Salazar, F. (2015). Assessing competition in the banking industry: A multi-product approach. Journal of Banking \& Finance, 50, 340-362.

Barros, C. P., \& Wanke, P. (2014). Banking efficiency in Brazil. Journal of International Financial Markets, Institutions and Money, 28, 54-65.

Belaisch, M. A. (2003). Do Brazilian banks compete? (No. 3-113). International Monetary Fund.

Blackorby, C., \& Russell, R. R. (1989). Will the real elasticity of substitution please stand up? (A comparison of the Allen/Uzawa and Morishima elasticities). The American Economic Review, $79(4), 882-888$.

Central Intelligence Agency, U.S. (2017). The World Factbook 2016-17. Retrieved March 6, 2019, from http://www cia gov/library/publications/the-world-factbook

de La Grandville, O. (1997). Curvature and the elasticity of substitution: Straightening it out. Journal of Economics, 66(1), 23-34.

de la Rosa, D., Ortiz, D., \& Otero, R. (2017). Use of Accounting and the Efficiency of Microenterprises in Mexico. Journal of Accounting and Finance, 17(9).

Dogan, C., \& Akay, G. H. (2016). Multi-sector specific factors model with two mobile factors. International Review of Economics \& Finance, 46, 136-147.

Gupta, S. D., Raychaudhuri, A., \& Haldar, S. K. (2018). Information technology and profitability: evidence from Indian banking sector. International Journal of Emerging Markets, 13(5), 10701087.

Liang, L. W., Cheng, C. P., \& Lin, Y. P. (2015). A Study of the Relationship between Bank Survival and Cost Efficiency. Journal of Finance, 3(2), 35-47.

Lubiani, G. G., Okunade, A. A., \& Chen, W. (2019). Sensitivity of generalized translog model estimates to alternative Pythagorean means: Evidence from US healthcare. Managerial and Decision Economics, 40(2), 141-149.

Oreiro, J. L., \& de Paula, L. F. (2010). Macroeconomic determinants of bank spread in Latin America: a recent analysis with special focus on Brazil. International Review of Applied Economics, 24(5), 573-590. 
Ouyang, X., \& Sun, C. (2015). Energy savings potential in China's industrial sector: from the perspectives of factor price distortion and allocative inefficiency. Energy Economics, 48, 117-126.

Ramasamy, M., Dhanapal, D., \& Murugesan, P. (2017). Effects of FDI spillover on regional productivity: Evidence from panel data analysis using stochastic frontier analysis. International Journal of Emerging Markets, 12(3), 427-446.

Rezitis, A. N. (2010). Evaluating the state of competition of the Greek banking industry. Journal of International Financial Markets, Institutions and Money, 20(1), 68-90.

Ripplinger, D. G., \& Bitzan, J. D. (2018). The cost structure of transit in small urban and rural US communities. Transportation Research Part A: Policy and Practice, 117, 176-189.

Stern, D. I. (2011). Elasticities of substitution and complementarity. Journal of Productivity Analysis, 36(1), 79-89. 